\title{
Aktualisasi Perilaku Hidup Bersih dan Sehat pada Siswa Sekolah Dasar di Kecamatan Kambu dan Poasia
}

\author{
Muhammad Hajrul Malaka, Ruslin, Zoraya Denok Rafhisya, Miftahul Fadli, Sunandar Ihsan, \\ La Ode Muhammad Fitrawan, Adryan Fristiohady \\ Fakultas Farmasi Universitas Halu Oleo, Kampus Hijau Bumi Tridharma Anduonohu, Jl. H. E. A. Mokodompit
}

Kendari, 93232

\begin{abstract}
ABSTRAK
Perilaku hidup bersih dan sehat (PHBS) adalah semua perilaku kesehatan yang dilakukan karena kesadaran pribadi sebagai hasil pembelajaran sehingga keluarga dan seluruh anggotanya mampu menolong diri sendiri pada bidang kesehatan serta memiliki peran aktif dalam aktivitas masyarakat. Anak merupakan aset terpenting dalam tercapainya keberhasilan suatu negara. Anak usia sekolah merupakan kelompok usia yang kritis karena pada usia tersebut rentan terhadap masalah kesehatan. Masalah kesehatan umum yang terjadi pada anak usia sekolah biasanya berkaitan dengan kebersihan perorangan dan lingkungan seperti gosok gigi yang baik dan benar, kebersihan diri, serta kebiasaan cuci tangan pakai sabun, serta membersihkan kuku dan rambut. Peningkatan pemahaman siswa tentang cuci tangan dan menggosok gigi diberikan menggunakan metode pelatihan yaitu memberikan pengetahuan dan praktik terkait cuci tangan dan menggosok gigi. Hasil yang diperoleh adalah kegiatan pelatihan berjalan dengan baik dan siswa aktif bertanya dan antusias dalam mempraktikkan angkah-langkah cuci tangan dengan menggunakan sabun dan air mengalir dan meggosok gigi dengan baik dan benar.
\end{abstract}

Kata kunci : Cuci Tangan, Anak, Gosok Gigi, PHBS

\section{Actualization of Clean and Healthy Behaviors in Primary School Students in Kambu and Poasia Subdistrict}

\begin{abstract}
Clean and healthy life behavior are all health behaviors that carried out because of personal awareness as a result of learning so that the family and all its members are able to help themselves in the health sector and have an active role in community activities. Childrens are the most important asset in achieving the success of a country. School-age children are a critical age group because at that age they are vulnerable to health problems. General health problems that occur in school-age children are usually related to personal hygiene and the environment such as good and correct brushing teeth, personal hygiene, and hand washing habits with soap, and cleaning nails and hair. Increasing student's understanding of hand washing and tooth brushing is given using training methods that are providing knowledge and practice regarding hand washing and brushing teeth. The results obtained were that the training activities went well and the students actively asked and were enthusiastic in practicing the steps to wash their hands using soap and running water and brushing their teeth properly and correctly
\end{abstract}

Keywords: Washing Hands, Brushing Teeth, Child, CHB

Penulis Korespondensi :

Adryan Fristiohady

Fakultas Farmasi Universitas Halu Oleo, Kendari, Sulawesi Tenggara

E-mail : adryanfristiohady@uho.ac.id

No. Hp : 08114101234 


\section{PENDAHULUAN}

Kesehatan merupakan harapan semua pihak, tidak hanya didominasi oleh perorangan, akan tetapi juga harus dimiliki oleh kelompok dan bahkan oleh masyarakat. Kesehatan adalah keadaan sehat, baik secara fisik, mental, spritual maupun sosial yang memungkinkan setiap orang untuk hidup produktif secara sosial dan ekonomis. Hal ini berarti bahwa kesehatan pada diri seseorang atau individu itu mencakup aspek fisik, mental, spiritual dan sosial demi tercapainya keadaan yang sejahtera bagi seseorang baik dengan produkivitasnya dan juga ekonominya. Derajat kesehatan dipengaruhi oleh 4 faktor yaitu faktor lingkungan, faktor perilaku, faktor keturunan dan faktor pelayanan kesehatan. Salah satu faktor yaitu faktor perilaku yang sangat berpengaruh dalam kesehatan seseorang, terutama dalam penerapan PHBS (Perilaku Hidup Bersih dan Sehat) baik di lingkungan pribadi, keluarga, maupun masyarakat (Andriansyah dan Desi, 2013; Hayden, 2009).

Perilaku hidup bersih dan sehat (PHBS) merupakan perilaku sehari-hari yang sehat dan dilakukan oleh kesadaran pribadi sebagai hasil pembelajaran, sehingga keluarga dan seluruh orang orang terdekat kita mampu mengedukasi diri sendiri pada bidang kesehatan serta memiliki peran aktif dalam aktivitas masyarakat (Permenkes, 2011). Perilaku hidup bersih sehat pada dasarnya merupakan suatu upaya untuk memberikan pengalaman mengenai pola hidup sehat melalui individu, kelompok ataupun masyarakat luas dengan jalur - jalur komunikasi sebagai media berbagi informasi. Ada berbagai informasi yang dapat dibagikan seperti materi edukasi guna menambah pengetahuan serta meningkatkan sikap dan perilaku terkait cara hidup yang bersih dan sehat. Perilaku hidup sehat pada tatanan sekolah ialah praktik kebiasaan hidup bersih dan sehat dalam kehidupan sehari-hari baik selama siswa berada di kelas maupun di luar kelas seperti siswa melakukan cuci tangan dengan sabun, melakukan sosok gigi secara teratur (Gustina dkk., 2018).

Hidup bersih dan sehat sendiri merupakan suatu hal yang seharusnya memang diterapkan dalam kehidupan sehari-hari oleh masyarakat sebagai salah satu cara menjaga kesehatannya. Mengingat kesehatan merupakan hal penting bagi setiap manusia mulai dari konsentrasi dalam bekerja dan beraktivitas dalam kehidupan seharihari. Anak merupakan kelompok yang paling rentan terserang penyakit (Khoirudin, dkk., 2015). Beberapa penyakit yang sering muncul akibat rendahnya perilaku hidup bersih dan sehat antara lain cacingan, diare, sakit gigi, sakit kulit, gizi buruk, dan lain sebagainya. Hal ini akan mempengaruhi tumbuh kembang anak dan kualitas kesehatannya (Banun, 2016). Menurut World Health Organization (WHO) menyebutkan bahwa diare terjadi di 
seluruh dunia dan menyebabkan $4 \%$ dari semua kematian. Secara umum diare membunuh sekitar 2,2 juta orang setiap tahun dan kebanyakan dari mereka adalah anak-anak di negara berkembang (Saputro dkk., 2013).

Masalah kesehatan umum yang terjadi pada anak usia sekolah biasanya berkaitan dengan kebersihan perorangan dan lingkungan seperti gosok gigi yang baik dan benar, kebersihan diri, serta kebiasaan cuci tangan pakai sabun, serta membersihkan kuku dan rambut (Gustina dkk., 2018). Mencuci tangan merupakan proses membersihkan kotoran dan debu secara mekanis dari kedua belah tangan dengan memakai sabun dan air. Tujuan mencuci tangan adalah untuk menghilangkan kotoran dan debu secara mekanis dari permukaan kulit dan mengurangi jumlah mikroorganisme. Mencuci tangan juga dapat menghilangkan sebagian besar virus yang menjadi penyebab berbagai penyakit, terutama penyakit yang menyerang saluran cerna, seperti diare dan saluran nafas seperti influenza (Achmadi, 2009).

Perilaku hidup bersih dan sehat harus ditanamkan sedini mungkin mulai dari tingkat dasar baik di rumah atau di sekolah dengan mengarahkan siswa agar selalu menjaga kesehatan. Banyak siswa sekolah dasar yang belum bisa menerapkan perilaku hidup bersih dan sehat baik di lingkungan rumah atau di sekolah. Misal kebiasaan hidup sehat di rumah dimulai dengan mencuci tangan sebelum makan, pakai alas kaki bila keluar rumah, dan menggunakan pakaian yang bersih. Kebiasaan hidup sehat di sekolah dimulai dengan dating di sekolah dengan tubuh yang bersih, pakaian dan alas kaki yang bersih, buang sampah ke tempat sampah, buang air besar dan kecil di kamar mandi atau WC lalu setelah dipakai dibersihkan. Kebiasaan tersebut sangat tepat ditanamkan sedini mungkin karena kebiasaan tersebut akan terbawa sampai dewasa nanti (Nugraheni dkk., 2018).

Promosi kesehatan di sekolah merupakan upaya untuk memberdayakan siswa, guru dan masyarakat di lingkungan sekolah agar tahu, mau dan mampu mempraktikkan PHBS sera berperan aktif dalam mewujudkan sekolah sehat (Rachmat, 2018). Selain pengetahuan peserta didik, peran pimpinan sekolah dan guru juga dibutuhkan untuk membudayakan PHBS di sekolah. Penelitian Diana dkk. (2014), menyatakan bahwa terdapat hubungan yang bermakna antara pengetahuan dan peran guru dengan pelaksanaan program PHBS, sehingga diperlukan pelatihan, penyuluhan dan memperbanyak media promosi (Souisa dkk., 2018).

\section{METODE}

Sosalisasi ini dilakukan pada bulan Juli - Agustus 2019 bertempat di gedung Sekolah Dasar. SDN 100 Kendari dengan jumlah siswa 35 yang terdiri dari kelas 3 dan 4, SDN 35 Kendari dengan jumlah siswa 42 yang terdiri dari kelas 
2A dan 2B, SDN 6 Kendari dengan jumlah siswa 25 dari kelas 3, dan SDN 51 Kendari dengan jumlah siswa 33 yang terdiri dari kelas 3A dan 3B.

Peningkatan perilaku ksehatan pada anak SD menggunakan metode sosialisasi, pendampingan dan penyedian alat dan bahan seperti sabun dan handsanitizer untuk cuci tangan dan paket menggosok gigi yaitu pasta gigi dan sikat gigi. Sosialisasi kesehatan ini dimulai dengan memberikan pengetahuan cuci tangan dan menggosok gigi kepada anak-anak yang baik dan benar serta pemutaran video animasi serta praktik cuci tangan. Setelah kegiatan pelatihan dilakukan, diadakan monitoring dan evaluasi untuk memastikan kegiatan berjalan dengan baik dan lancar.

\section{HASIL DAN PEMBAHASAN KEGIATAN}

(PHBS) adalah upaya untuk memberikan pengalaman belajar atau menciptakan suatu kondisi bagi perorangan, keluarga, kelompok dan masyarakat dengan membuka jalur komunikasi, memberikan informasi dan melakukan edukasi untuk meningkatkan pengetahuan, sikap dan perilaku (Adriansyah dan Nurul, 2017). PHBS memiliki tujuan yaitu meningkatkan pengetahuan, kesadaran, kemauan dan kemampuan masyarakat agar hidup bersih dan sehat serta masyarakat termasuk swasta dan dunia usaha berperan serta aktif mewujudkan derajat kesehatan yang optimal (Andriansyah dan Desi, 2013).

Salah satu program PHBS yaitu PHBS di lingkungan sekolah, lingkungan yang dimaksud ialah lingkungan sekolah yang terletak ditengah perkotaan, di dekat pusat perbelanjaan/pasar, serta sekolah yang terdapat di pinggiran kota, yang mana sekolah sekolah tersebut merupakan institusi pendidikan sehingga menjadi target PHBS. Hal ini disebabkan karena terdapatnya banyak data yang menampilkan bahwa sebagian besar penyakit yang sering diderita anak usia sekolah (usia 6-10 tahun) ternyata berkaitan dengan PHBS. Selain itu, masih kurangnya pelaksanaan PHBS di lingkungan sekolah dapat menyebabkan dampak lain, yaitu kurang nyamannya suasana belajar akibat lingkungan kelas yang kotor, menurunnya prestasi dan semangat belajar siswa (Maryunani, 2012; Proverawati, dkk, 2012).

Tujuan dilakukannya kegiatan sosialisasi PHBS di lingkungan sekolah yaitu meningkatkan pemahaman dan wawasan anak-anak yang merupakan generasi penerus bangsa tentang pentingnya hidup bersih dan sehat, mampu meningkatkan kesadaran anakanak sekolah dalam berperilaku PHBS, dan terdapat perubahan perilaku yang lebih baik pada anak-anak dalam PHBS.

Sosalisasi ini dilakukan pada bulan Juli - Agustus 2019 bertempat di gedung Sekolah Dasar. Peserta pada sosialisasi ini adalah murid sekolah dasar yang ada di Kecamatan Kambu 
dan Poasia. Kegiatan pertama yang kami lakukan di beberapa SD, yaitu SDN 100 Kendari dengan jumlah siswa 35 yang terdiri dari kelas 3 dan 4, SDN 35 Kendari dengan jumlah siswa 42 yang terdiri dari kelas 2A dan 2B, SDN 6 Kendari dengan jumlah siswa 25 dari kelas 3, dan SDN 51 Kendari dengan jumlah siswa 33 yang terdiri dari kelas 3A dan 3B.

Materi yang disajikan adalah materi penyuluhan tentang cuci tangan yang baik dan benar serta pemutaran animasi tentang langkah-langkah cuci tangan dengan sabun dan air mengalir. Setelah materi diberikan, siswa diminta menjelaskan kembali materi yang telah diberikan. Pemberian materi ini diharapkan memberikan pemahaman

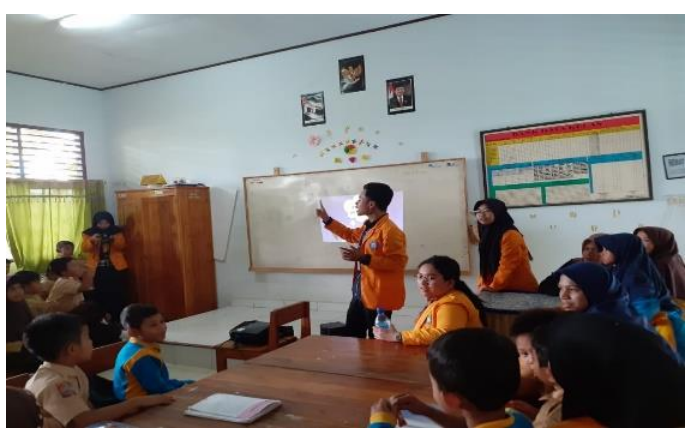

kepada siswa sekolah dasar tentang pentingnya perilaku hidup bersih dan sehat seperti, cuci tangan menggunakan sabun dengan air mengalir sebelum dan sesudah melakukan aktivitas dan cuci tangan sebelum dan sesudah makan.

Kegiatan sosialiasi cuci tangan di SDN 100 Kendari, SDN 35 Kendari, SDN 6 Kendari, dan SDN 51 Kendari dapat berjalan dengan baik dan lancar. Siswa sangat antusias dan dapat bekerjasama dengan baik, serta dapat mempraktikkan mencuci tangan dengan sabun menggunakan air mengalir. Setelah kegiatan pelatihan dilakukan, diadakan monitoring dan evaluasi untuk memastikan kegiatan berjalan dengan baik dan lancar.

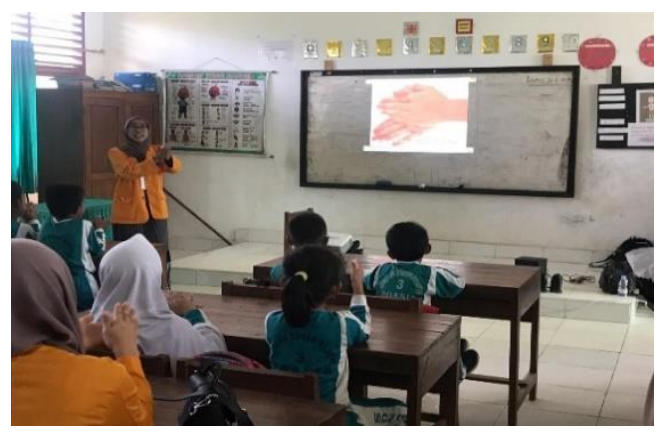

Gambar 1. Pemberian Materi Cuci Tangan

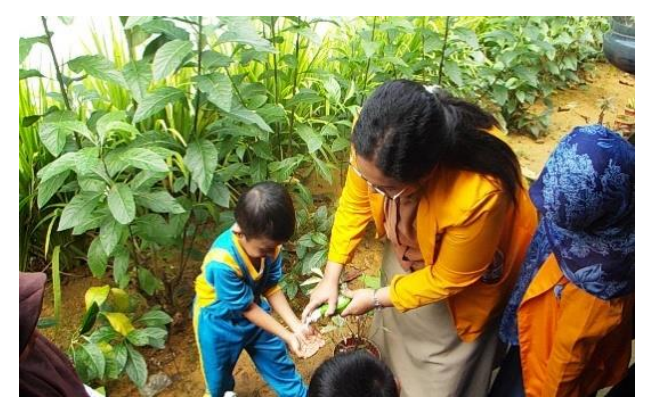

Gambar 2. Penerapan Cuci Tangan 
Salah satu upaya efektif menjaga kebersihan adalah dengan mencuci tangan. Tangan manusia merupakan tempat berdiamnya beraneka ragam kuman, seperti virus, bakteri, dan bisa juga jamur. Tangan yang kotor dapat menjadi media penularan berbagai macam penyakit (Zein dan Emir, 2019). Mencuci tangan dengan sabun dan air mengalir adalah hal wajib yang harus dilakukan untuk menjaga kesehatan tubuh. Membilas tangan dengan air mengalir akan membantu menyapu kotoran dan kuman yang menempel di tangan. Terkadang, mencuci tangan dianggap merupakan hal yang sepele. Kebanyakan orang hanya menggosok tangan dengan air tanpa menggunakan sabun. Hal ini menyebabkan kuman masih banyak yang menempel. Kuman dan virus dapat bertahan hidup hingga 2 jam di atas permukaan kulit, meja, gagang pintu, mainan, dan lain-lain. Kebersihan tangan yang tidak terpelihara dengan baik dapat menyebabkan penyakit seperti diare, batuk, pilek, dan demam. Oleh karena itu, mencuci tangan dengan baik dan benar menggunakan sabun dan air mengalir sangat berguna untuk memutus rantai penyebaran berbagai macam penyakit.

Tindakan cuci tangan yang dilakukan dengan baik dapat menurunkan kejadian diare (Agustin, 2019). Mencuci tangan menggunakan sabun dengan bahan dan cara yang benar, dan saat yang tepat, akan menurunkan angka kejadian diare sebesar $47 \%$ dan angka kejadian Infeksi Saluran Pernafasan Akut (ISPA) sebesar 30\%. Data WHO menunjukkan penyebab kematian terbesar bagi bayi dan balita di dunia adalah ISPA dan diare. Cuci tangan menggunakan sabun bisa melepaskan kuman penyebab infeksi dengan murah dan mudah, sehingga dianggap sebagai salah satu cara efektif mencegah terjadinya penyakit (Zein dan Emir, 2019).
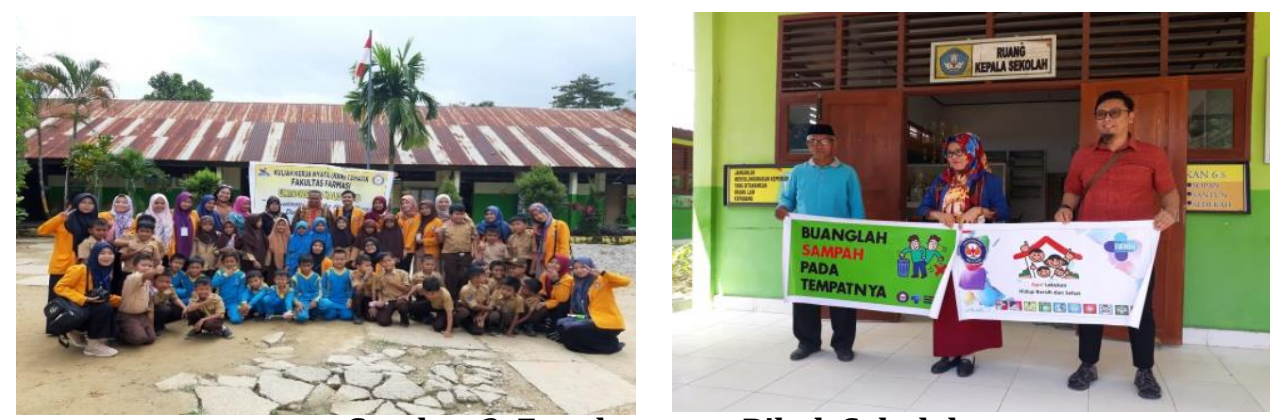

Gambar 3. Foto bersama Pihak Sekolah 


\section{KESIMPULAN}

Kegiatan sosialisasi cuci tangan di Kecamatan Kambu dan Poasia dapat berjalan dengan baik dan lancar. Siswa antusias dan dapat bekerjasama dengan baik, serta dapat mempraktikkan mencuci tangan dengan sabun dan air mengalir serta menggosok gigi dengan baik dan benar.

\section{UCAPAN TERIMA KASIH}

Terima kasih kepada Lembaga Penelitian dan Pengabdian Kepada Masyarakat (LPPM) Universitas Halu Oleo yang telah memberikan pendanaan kegiatan melalui skim Pengabdian Kepada Masyarakat Terintegrasi KKN Tematik Tahun 2019.

\section{Daftar Pustaka}

Achmadi, U. F., 2009, Kesehatan

Lingkungan, Kesehatan Masyarakat, 3, 148.

Adriansyah, A. A., dan Nurul, J. F., 2017, Implementasi Perilaku Hidup Bersih Dan Sehat (PHBS) Dalam Membangun Gaya Hidup Sehat Sejak Dini Di Sekolah Dasar Negeri (SDN) Lengkong 1, Desa Lengkong, Kecamatan Mojoanyar Kabupaten Mojokerto, Community Development Journal, Vol. 1(2).

Agustin, R.A., 2019, Perilaku Kesehatan, Prevalensi Penyakit dan Upaya Peningkatan Status Kesehatan Anak Sekolah, Jember : CV. Pustaka Abadi.
Andriansyah, Y., dan Desi, N. R., 2013, Penyuluhan dan Praktik PHBS (Perilaku Hidup Bersih Sehat) dalam Mewujudkan Masyarakat Desa Peduli Sehat, Jurnal Inovasi dan Kewirausahaan, Vol. 2(1).

Banun, T. S.,2016, Hubungan antara Pengetahuan PHBS dengan Pola Hidup Sehat Siswa di SD Tamanan, Jurnal Pendidikan Guru Sekolah Dasar, Edisi 14.

Diana, F. M., Susanti, F., \& Irfan, A., 2014, Pelaksanaan Program Perilaku Hidup Bersih dan Sehat (PHBS) di SD Negeri 001 Tanjung Balai Karimun, Jurnal Kesehatan Masyarakat, Vol. 8(1).

Gustina, E., Fakhri, A., dan Wawan, S., 2018, Peningkatan Perilaku Sehat pada Siswa Sekolah Dasar melalui PHBS di Desa Gondanglegi dan Pucangan, Kecamatan Ambal, Kabupaten Kebumen, Jurnal Pemberdayaan Publikasi Hasil Pengabdian kepada Masyarakat, Vol. 2(1).

Hayden, J., 2009, Introduction to Health Behavior Theory, Canada: Jones and Bartlett Publishers.

Kementerian Pendidikan Indonesia. 2011. Mengembangkan perilaku sehat pada naka usia 2-4 tahun. Direktorat Pembinaan Pendidikan Anak Usia Dini. Jakarta

Khoiruddin, Kirnantoro, dan Sutanta, 2015, Tingkat Pengetahuan Berhubungan dengan Sikap Cuci 
Tangan Bersih Bersih Pakai Sabun Sebelum dan Setelah Makan Pada Siswa SDN Ngebel, Tamantirta, Kasihan, Bantul, Yogyakarta, Journal Ners and Midwifery Indonesia, Vol. 3(3).

Maryunani, A., 2012, Perilaku Hidup

Bersih dan Sehat, Jakarta: CV Trans Info Media.

Nugraheni, H., Sofwan, I., dan Suhat, 2018, Buku Ajar Promosi Kesehatan Berbasis Sekolah, Yogyakarta: Deepublish Publisher.

Peraturan menteri Kesehatan Republik Indonesia. 2011. Pedoman Pembinaan Perilaku Hidup Bersih dan Sehat (PHBS), Jakarta.

Proverawati, dkk., 2012, Perilaku Hidup Bersih dan Sehat, Yogyakarta.

Rachmat, H.H., 2018, Penguatan Upaya Kesehatan Masyarakat dan Pemberdayaan Masyarakat Bidang Kesehatan di Indonesia, Yogyakarta: Gadjah Mada University Press.

Saputro, W., Lia, Y.B., dan Herawati, 2013, Perilaku Hidup Bersih Dan Sehat (PHBS) Dengan Kejadian Diare Pada Anak Sekolah Dasar (SD), $D K$, Vol. 1(1).

Souisa, G.V., Ivy, V.L., Samuel, T., dan Bellytra, T., 2018, Peningkatan Perilaku Hidup Bersih Dan Sehat (Phbs) Pada Pendidik Dan Peserta Didik Di Kecamatan Leihitu Barat Kabupaten Maluku Tengah, Jurnal Pengabdian Kepada Masyarakat, Vol. 24(3).
Zein, U. dan Emir, E.N., 2019, Buku Ajar Ilmu Kesehatan (Memahami Gejala, Tanda dan Mitos), Yogyakarta: Deepublish Publisher. 